\title{
Extended length rotation to integrate timber and pine nut production with the conservation of structural diversity in a Pinus pinea $(\mathrm{L}$.) forest
}

\author{
Fernando MonTES $^{\text {a* }}$, María J. HERNÁNDEZ ${ }^{\mathrm{b}}$, Rafael CALAMA ${ }^{\mathrm{a}}$, Isabel CAÑELLAS ${ }^{\mathrm{a}}$ \\ ${ }^{\text {a }}$ CIFOR-INIA, Ctra. de A Coruña km 7,5, 28040 Madrid, Spain \\ ${ }^{\mathrm{b}}$ C/ Isaac Albéniz 22, 28290 Madrid, Spain
}

(Received 6 July 2005; accepted 8 February 2006)

\begin{abstract}
The age structure of forests is one of the most important features for sustainable forest management. In this paper, an age distribution model is proposed which extends the age range in managed Pinus pinea $\mathrm{L}$. forests. The method, termed extended rotation, consists of defining the theoretical global structure formed by several management circles, gradually reducing the area managed through longer rotations. The extended rotation method has been applied to obtain a target age distribution in a Pinus pinea forest. For this age distribution, the timber and pine nut (pine nut) production has been predicted for the next 40 years and compared with the most commonly applied method in Pinus pinea stands, the scattered periodic blocks management system. The application of the extended rotation method leads to a $15 \%$ timber yield loss, whereas there is a $10 \%$ pine nut production increment and the diversity of the age distribution and the basal area heterogeneity increase in the long term.
\end{abstract}

rotation age / forest management / Pinus pinea / pine nut production / age structure model

Résumé - Révolution étendue pour intégrer la production de bois et la production de pignes avec une conservation de la diversité structurelle dans les forêts de Pinus pinea L. La structure des âges des forêts est un des aspects les plus importants pour la gestion forestière durable. Dans cet article, un modèle de distribution par âges qui permettra d'élargir l'intervalle d'âges représenté en forêts aménagées de Pinus pinea L. est proposé. Cette méthode, dénommée « révolution étendue », est basée sur la définition de la structure théorique formée par plusieurs séries de révolutions différentes, et la réduction graduelle simultanée de la surface des séries des plus longues rotations. La méthode de révolution étendue a été appliquée sur une pinède de Pinus pinea afin d'obtenir une structure des âges de référence. Avec cette structure des âges, les productions de bois et de pignon ont été quantifiées pour les prochaines 40 années, et comparées avec la méthode du «groupe bleu ». La méthode de révolution étendue entraîne une réduction de $15 \%$ dans la production de bois, tandis que la production de pignes augmente en $10 \%$ et la diversité de la distribution par âge et l'hétérogénéité de la surface terrière augmentent à long terme.

rotation / aménagement forestier / Pinus pinea / production de pignes / modèle de distribution par âge

\section{INTRODUCTION}

Since the beginnings of silviculture in the 18th century, its main purpose has been the sustainable management of forests [20], which in turn means to kept the forest ecosystem stable in a defined functional state [11]. Today, the exploitation of forests, which represent a major part of natural ecosystems, is also concerned with the conservation of species and their habitats. Several studies stress the relationship between the forest structure and the habitat availability [2,21,29], so one of the main contributions of forestry to biodiversity conservation lies in maintaining the structural diversity of forests [30].

Forest management leads to changes in horizontal and vertical structure [19,27], in dead wood [14,32] and in the species composition $[26,36]$. Some silvicultural practices can enhance biological diversity in managed forests, such as retaining old trees [31], maintaining adequate levels of dead wood [35], establishing mixed stands [28] or extending rotation lengths [9].

\footnotetext{
*Corresponding author: fmontes@inia.es
}

One of the major differences between natural and managed forests is the lack in managed forests of stands in late seral stages because the rotation truncates the age distribution [33]. The rotation length and the regeneration fellings are of great importance in the stand dynamics [10]. When timber production is the main concern, the rotation is determined taking into account the rate of growth, the longevity of species and the economic circumstances. If the rotation exceeds the age at which the mean annual timber yield increment is maximum there will be an annual yield loss, although the demand of the market sometimes lead to make certain dimensions more valuable. Stem rot in old trees is common for most tree species and seriously affects the viability of long rotations. For species that have important non-timber productions, the rotation is set just before the productivity declines, although the age when this occurs shows sometimes a great variability among trees and generally the trees with largest productions are not felled. The rotation is, at the same time, the age when the regeneration process begins in managed forests. Regeneration is essential 
to guarantee sustainable management, and is one of the main concerns in Mediterranean forests. Nevertheless, extending rotation age might diversify habitat structure in managed forests [18]. Several approaches, such as multi-cohorts management [15] or the use of successively longer rotations in decreasing proportions of the forest [16], have been proposed to emulate the natural pattern. The theoretical age structure under a natural disturbances regime would be a negative exponential distribution "tailing" into the older ages $[3,16,33]$.

Stone pine (Pinus pinea L.) is a typical Mediterranean species which is exploited commercially for its timber and pine nuts. Together with these main commercial productions, stone pine forests play an important role as landscape generators, recreational areas, and soil protectors. Management of these forests has traditionally focused on maintaining both commercial productions, optimising the one in better market conditions. Commercial cone crops don't start till an age of 40 years, and the trees with larger production, usually freegrowth trees which shows a well developed umbrella-like crown, maintain an increasing tendency up to 140 years [5]. Due to this, stand cone production is favoured by keeping low stand densities and retaining old, large fruit producer trees after regeneration fellings are carried out. This usually lead to two or three storied stands. In the other hand, timber production is favoured by high stand densities under even-aged structure and by cutting before Phellinus pini (Brot.:Fr) Ames. rot affects severely stem timber quality, which start to occur, on worse qualities, at an age of 60 [13].

Taking into account all these factors, where timber is the most interesting production rotation is set between 60 80 years [1], and stands have been traditionally regenerated applying strip clear cuttings followed by artificial seeding. For a mixed production of timber and pine nuts, rotation lengths between 80 and 120 year have been proposed [12], whereas rotation can be extended up to 150 years if the priority is pine nut production together with landscape, protective or recreational use [38]. In these forests, shelterwood uniform systems or group selection system are being widely applied. For a intermediate site quality, annual timber production ranges between $2.2 \mathrm{~m}^{3} / \mathrm{ha} /$ year under a 80 years rotation and timber production oriented silviculture, and $1.6 \mathrm{~m}^{3} / \mathrm{ha} /$ year, under a 120 years rotation and pine nut production oriented silviculture, being worth considering that the rot infection degree is much higher at age of 120 than at the age of 80 . In the other hand, mean annual cone production increases from approximately $40 \mathrm{~kg} / \mathrm{ha} /$ year, in the case of 80 years rotation and timber oriented silviculture, to around $165 \mathrm{~kg} / \mathrm{ha} / \mathrm{year}$ if rotation is set at the age of 120 years [5].

The aim of this paper is to propose a method to obtain a target permanent age distribution that considers the preservation of forest areas in overmature stages, by assigning different length rotations to different patches within a stand depending on site quality. As a case study, an application of the method is carried out in a Pinus pinea forest, comparing proposed management system with a classical management method on a basis of both timber and cone production.

\section{AGE DISTRIBUTION MODEL}

The method used to define the age distribution, termed "extended rotation" (ER), consists of defining the theoretical global structure formed by several management circles with a different rotation each, in order to reach a permanent age distribution that includes old stands, gradually reducing the area managed through longer rotations. This theoretical model is used to calculate the area that each age class must occupy, that is the data to be used in practice.

The Figure 1 show the division of a theoretical rectangular forest in $N$ management circles, each with a different rotation. In each management circle an equilibrate distribution of age classes is established, each age class occupying a theoretical area that is represented by a different colour. The Figure 1 shows the age of the stand within each block during 8 consecutives periods of 20 years each, being the area occupied by each age class always the same. The largest management circle, that is the one where rotation is shorter, occupy a surface $S_{1}=S \times\left(1-r_{1}\right)$, being $S$ the total forest area and $r_{1}$ the fraction of the forest area occupied by the rest of the management circles. The second management circle occupy $1-r_{2}$ of the rest (i.e. $\left.S_{2}=\left(S-S_{1}\right) \times\left(1-r_{2}\right)\right)$, the following $S_{3}=\left(S-\left(S_{1}+S_{2}\right)\right) \times\left(1-r_{3}\right)$, and so on (Fig. 1), with $0 \leq r_{i} \leq 1$. The theoretical area occupied by the different age classes in each management circle is $S_{i} \cdot t / T_{i}$, with $i=1, \ldots, N$, being $\mathrm{S}_{i}$ the management circle area, $t$ the length of regeneration period (that equals age class width) and $T_{i}$ the rotation age [23], so an equilibrate distribution of age classes is established within each management circle. In the largest management circle, the rotation is defined in terms of the main production and termed "base rotation" $\left(T_{b}\right)$. For each of the other management circles, ordered in descending size, the rotation is respectively $T_{b}+t, T_{b}+2 t, T_{b}+3 t$ and so on till $T_{b}+(N-1) \times t$. This leads to a permanent age distribution in the forest with the area occupied by each age class constant till the age of $T_{b}$ and successively decreasing from $T_{b}$ to the age of $T_{b}+(N-1) \times t$.

In the Figure 1 the area occupied by the 80-100 age class in year 40 is highlighted. The stand located in a part of this area had passed in the next period to the 100-120 age class, and the rest had been felled, being replaced by a 0-20 years old stand. As can be seen in Figure 1, during a period of 160 years some zones of the forest have been felled and regenerated twice, whereas other zones have not been felled at all.

The area occupied by the $\left[T_{b}+(i-1) \cdot t\right]-\left[T_{b}+i \cdot t\right]$ age class, $s_{\left(T_{b}+(i-1) \cdot t, T_{b}+i \cdot t\right)}$, is given by:

$$
S_{\left(T_{b}+(i-1) \cdot t, T_{b}+i \cdot t\right)}=\sum_{j=i}^{N} S_{i} \cdot \frac{t}{T_{b}+(j-1) \cdot t}
$$

where $S_{i}$ is the area occupied by the theoretical management circle $i, N$ is the number of management circles established, $T_{b}$ is the base rotation and $t$ is the age class width. Expanding $S_{i}$ as function of $r_{i}$, the ratio between the extent of the sum of the theoretical areas with a rotation longer than $T_{b}+(i-1) \times t$ and the sum of the areas with a rotation equal to or longer than 


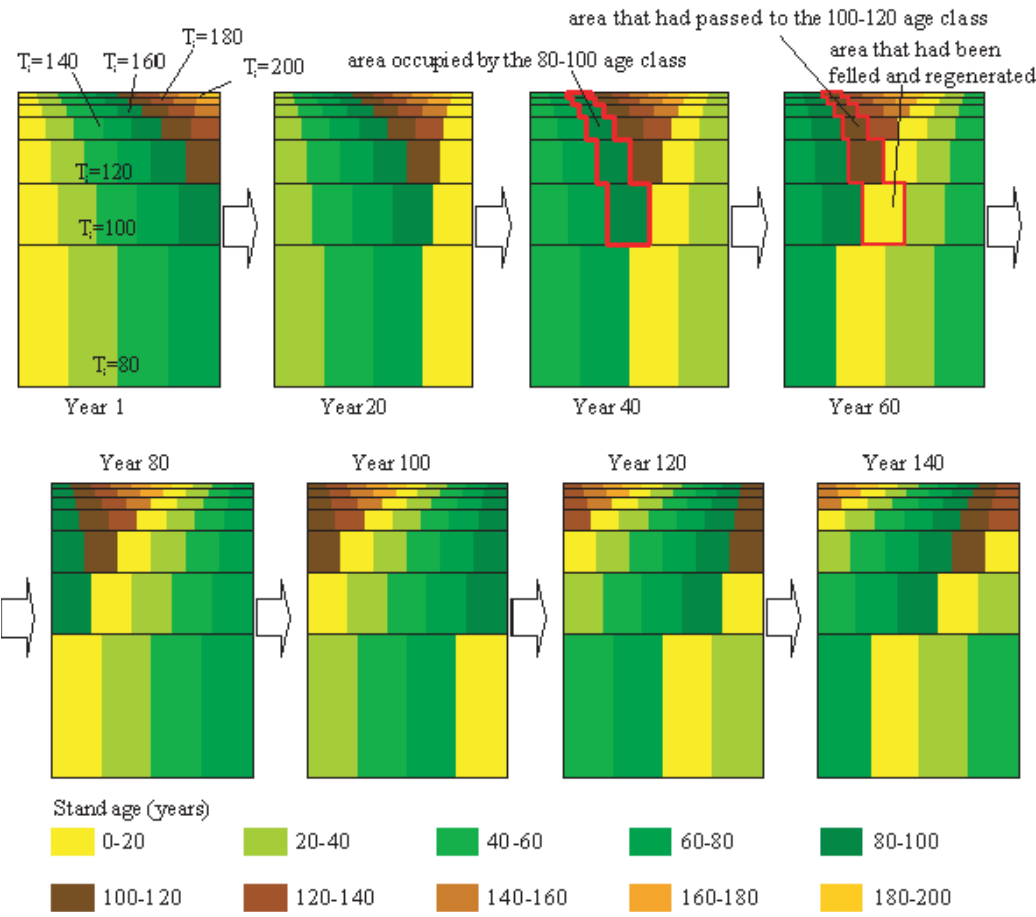

Figure 1. Distribution of age classes in a theoretical rectangular forest with a base rotation of 80 years, extended length rotation up to 200 years and regeneration period of 20 years, during a period of 140 years. The management circles are delimited by horizontal boundaries and the area occupied by each age class within each management circle is represented by different greys. (A color version of this figure is available at www.edpsciences.org/forest.)
$T_{b}+(i-1) \times t:$

$$
\begin{aligned}
S_{\left(T_{b}+(i-1) \cdot t, T_{b}+i \cdot t\right)} & =\left\{\sum_{j=i}^{N-2}\left(\left(1-r_{j+1}\right) \cdot\left[\left(\prod_{k=1}^{j} r_{k}\right) \cdot \frac{t}{T_{b}+j \cdot t}\right]\right)\right. \\
& \left.+\left(\prod_{j=1}^{N} r_{j}\right) \cdot \frac{t}{T_{b}+n \cdot t}\right\} \cdot S .
\end{aligned}
$$

Table I shows the $r_{i}$ value of calculated through a geometric series, given in Equation (3).

$$
r_{i}=\frac{1}{\sqrt{1+N-i}} .
$$

The Figure 2 shows the proportion of the area of the forest that each age class occupies with the age class distribution, calculated through Equation (2).

\section{CASE STUDY: APPLICATION OF THE EXTENDED LENGTH ROTATION MODEL TO A PINUS PINEA FOREST}

\subsection{Data}

As study case a 276 ha $P$. pinea forest, situated in the Northern Plateau region of Spain, was chosen. An inventory was carried out through a systematic sample of 37 circle plots with a radius of $13 \mathrm{~m}$ in a $250 \mathrm{~m}$ grid. Within each plot, the diameter at breast height of every tree higher than $1.30 \mathrm{~m}$ was measured as well as the height of the highest tree of the dominant stratum. In the highest tree of the dominant stratum the upper
Table I. $r_{i}$ (ratio between the extent of the theoretical area with a rotation of $T_{b}+i \times t$ and the sum of the areas with a rotation equal to or longer than $T_{b}+i \times t$ ) for $i=1, \ldots, N$ for the geometric series defined in Eq. (3). $T_{b}=$ base rotation, $t=$ regeneration period and $N=$ number of theoretical management circles.

\begin{tabular}{ll}
\hline$T$ & $r_{i}$ \\
\hline 80 & 0.41 \\
100 & 0.45 \\
120 & 0.50 \\
140 & 0.58 \\
160 & 0.71 \\
180 & 1.00 \\
200 & - \\
\hline
\end{tabular}

identifiable sequence of five annual shoots was selected and the height of each of the five shoots was measured to find the dominant height, site index and age of the plot (see next section). The number of pine saplings between 0.20 and $1.30 \mathrm{~m}$ height was also recorded.

\subsection{Site index and age of the stand}

\subsubsection{Site index and age estimation for the inventory plots}

The height of the five annual shoots of the sampled dominant tree were used to calculate the site index for each plot, taking into account that because of the climate of the study region, characterised by a long summer drought and cool winters, the growth of this species is limited to a single shoot per year. The dominant height difference equation fitted by 


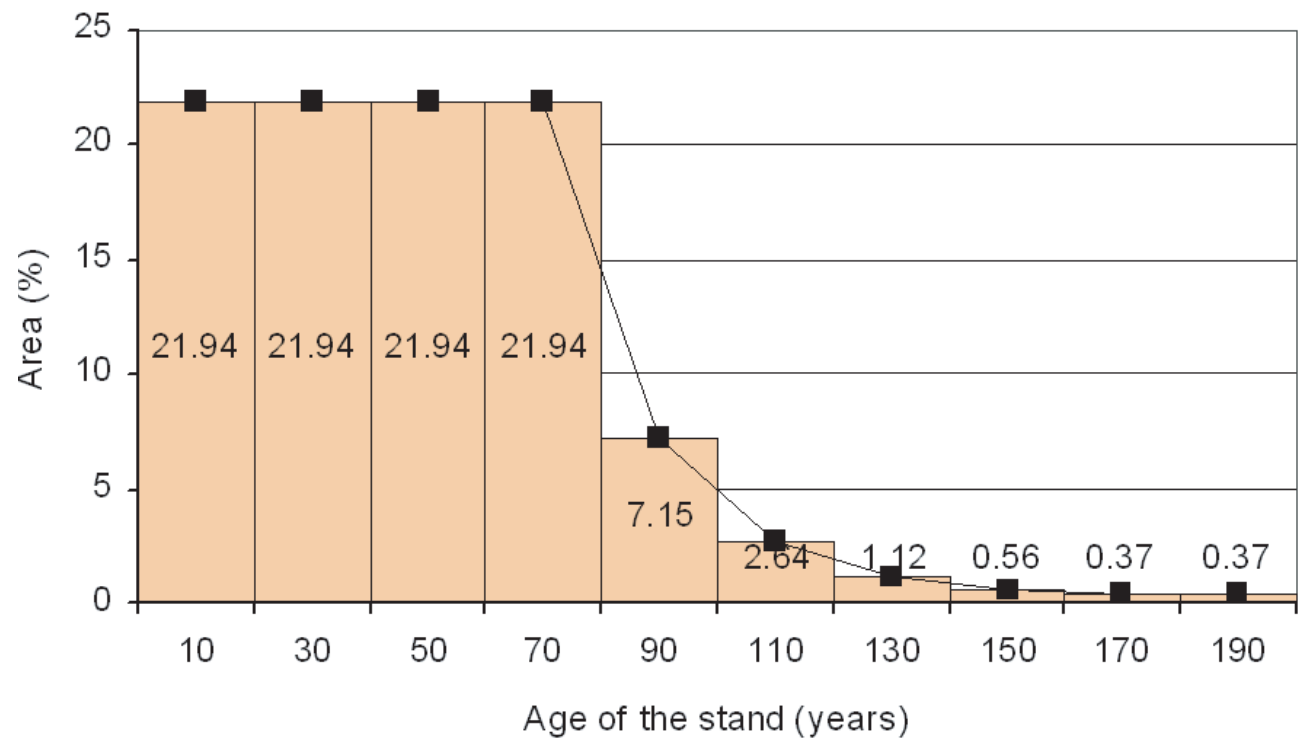

Figure 2. Percentage of the total forest area occupied by each age class calculated through Equation (3).
Calama et al. [4] for the species in the Northern Plateau region (Eq. (4)) was used.

$$
H_{2}=\exp \left\{5.2613+\left(\ln \left(H_{1}\right)-5.2613\right) \cdot\left(T_{2 / T_{1}}\right)^{-0.2576}\right\} .
$$

We knew the height of the tree at the end $\left(\mathrm{H}_{2}\right)$ and at the beginning $\left(\mathrm{H}_{1}\right)$ of the five year period, as well as the difference between the age at the end of the period $\left(\mathrm{T}_{2}\right)$ and the age at the beginning $\left(\mathrm{T}_{1}\right)$ (five years). Given the polymorphic and reciprocal character of Equation (4), it was possible to estimate $T_{2}$ and $\mathrm{T}_{1}$, and a site index (SI) for the plot, defined as dominant height at age 100 year.

\subsubsection{Kriging prediction of site index and age}

To estimate the site index and stand age at forest compartment level, block ordinary kriging was used. In order to carry out the ordnary kriging, the spherical variogram model [17], commonly used to model environmental variables, was fitted using the minimum weighted squares method (WLS) [7] to the empirical variogram, given by:

$$
\hat{\gamma}(d)=\frac{1}{2 \cdot N(d)} \sum_{a=1}^{N(d)}\left[z\left(u_{a}\right)-z\left(u_{a}+d\right)\right]^{2}
$$

where $N(d)$ is the number of pairs of samples $u_{a}$ and $u_{a}+d$ which distance from each other is within the distance lag centred at $d$, and $z\left(u_{a}\right)$ and $\mathrm{z}\left(u_{a}+d\right)$ are the values that the variable $z$ takes at samples $u_{a}$ and $u_{a}+d$. The experimental variogram and fitted model for the site index and age of the stand are shown in Figure 3.

The ordinary kriging prediction $p\left(Z, s_{0}\right)$ for the value of the regionalized variable $Z\left(s_{0}\right)$ at point $s_{0}$, from the $n$ observed values $Z\left(s_{i}\right)$ of the variable at the sampled points $s_{i}$, is given by the ordinary kriging equations:

$$
\begin{aligned}
& p\left(Z, s_{0}\right)=\sum_{i=1}^{n} \lambda_{i} \cdot Z\left(s_{i}\right) \\
& \sum_{i=1}^{n} \lambda_{i}=1 .
\end{aligned}
$$

The coefficient vector $\lambda_{i}$ is obtained by minimizing the mean squared error of the prediction. The explicit formulae given by Cressie [7] were used to calculate $\lambda_{i}$. The estimation for the average value of a variable over a forest compartment was undertaken using block kriging. The standard errors of the block prediction ranged between $2.5-10.2 \%$ for the estimated SI and between $5.0-14.1 \%$ for the estimated age. The distribution of the age of the dominant strata and the site index within the forest area can be seen in Figure 4. The classification of the forest area in function of the stand age and the site index is shown in Table II.

\subsection{Stem rot risk evaluation}

García and Montero [13] found that the risk of stem rot by Phellinus pini in Pinus pinea is related to the age of the stand, the height and the basal area $\left(R^{2}=0.6681\right)$, carrying out a discriminant analysis to classify the expected degree of rot from these three variables (Tab. III). The discriminant functions shown in Table III can be used to calculate the most likely of the four rot risk classes as a function, for each fixed basal area, of the age and the dominant height of the stand, obtaining for each value of basal area a graphic similar to the one shown in Figure 5, that corresponds to the mean basal area calculated from the inventory plots $\left(18 \mathrm{~m}^{2} / \mathrm{ha}\right)$. If the site index curves are overlapped to the rot risk classes, we find that in the stands with a lower site index, Phellinus pini appears earlier than in zones of better site quality. 


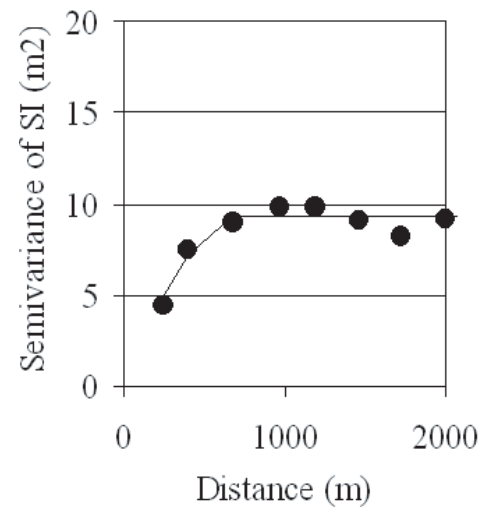

Distance (m)

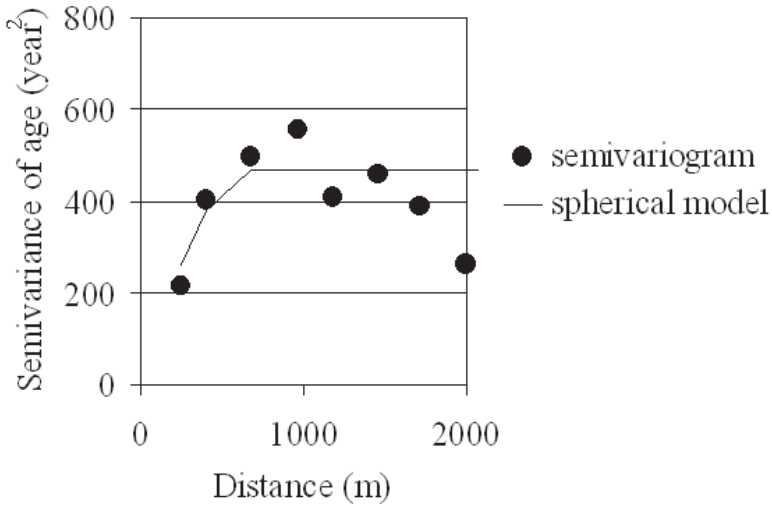

Figure 3. Experimental semivariogram and the fitted spherical model using the weigted least squares $(W L S)$ for the site index $(S I)$ (a) and the stand age (b). a

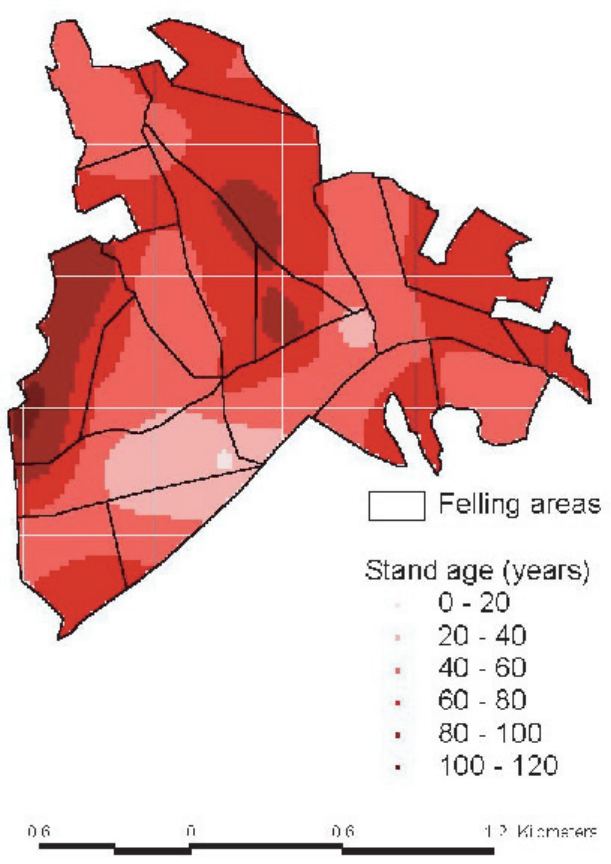

b

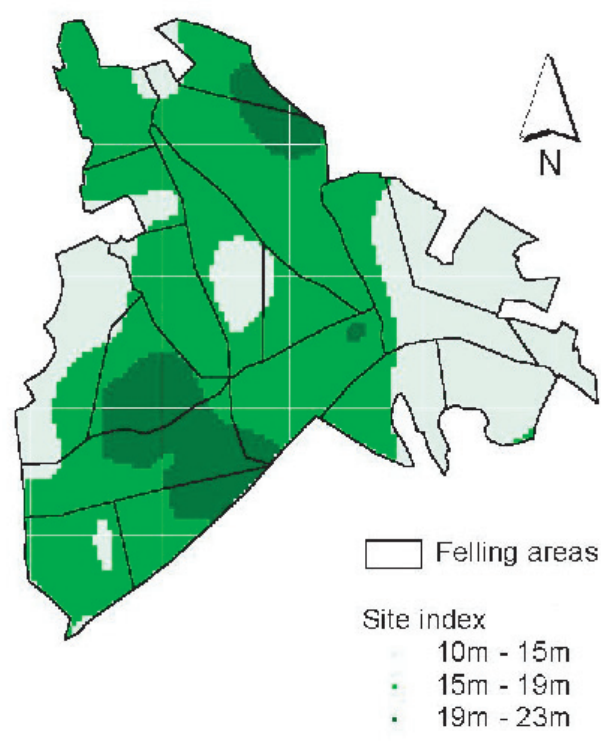

Figure 4. Ordinary kriging prediction of the age of the stand obtained using Equation 1 (a) and the site index following the model of Calama et al. [4] (b). (A color version of this figure is avialable at www.edpsciences.org/forest.)

\subsection{Definition of the age distribution model}

Figure 2 shows the theoretical age class distribution that would result of the application of the ER method in the 276 ha forest used as study case, with $r_{i}$ given by Equation (3) (Tab. I). If a 80 year base rotation is established we may expect serious rot to be limited to areas where the site index is III (Fig. 4 and Tab. II). As management focuses in both timber and pine nuts, the theoretical area where the base rotation ( 80 years) will be applied may be set about $2 / 3$ of the total area (182.2 ha), which is the area with site index III (67.1 ha) and part of the area with site index II (that is, following Tab. II, 163.5 ha). The maximum length rotation is set at 200 years, which is considered the age limit for cone production.

As can be seen in Figure 2, most of the forest is less than 150 years old, so there will be little rot infection. The
Table II. Classification of the forest area (ha) derived from the kriging of the site index defined by Calama et al. [4] and the stand age calculated through Equation (4).

\begin{tabular}{lccc}
\hline & \multicolumn{3}{c}{ Site index } \\
\hline Stand age (years) & I & II & III \\
\hline $0-20$ & 0.3 & 0.0 & 0.0 \\
$20-40$ & 19.1 & 2.4 & 0.0 \\
$40-60$ & 15.4 & 75.7 & 16.5 \\
$60-80$ & 10.6 & 70.1 & 37.4 \\
$80-100$ & 0.0 & 14.9 & 11.7 \\
$100-120$ & 0.0 & 0.4 & 1.5 \\
\hline
\end{tabular}

proportion of the ith age class that must reach the ith +1 age class should be established taking into account the condition and age distribution of the forest. The 160-180 and the 
Table III. Discriminant functions for stem rot (García and Montero, 2001), which give the probability of having a determined rot affection state. $T$ : age (years) calculated through Equation (4) for the dominant tree selected in each plot; $G$ : basal area ( $\mathrm{m}^{2} / \mathrm{ha}$ ) in the plot; Ho: height (m) dominant tree of the plot.

\begin{tabular}{lll}
\hline Class & Rot affection & Discriminant function \\
\hline$R C 1$ & Sound stems & $-3.063+0.010 T-0.024 G+0.777 H_{o}$ \\
$R C 2$ & One or two stems slightly rotted & $-6.158+0.075 T+0.007 G+0.765 H_{o}$ \\
$R C 3$ & Most stems sound but some moderate or deep rotting & $-10.204+0.126 T+0.113 G+0.622 H_{o}$ \\
$R C 4$ & Most trees with deep rotting & $-12.594+0.222 T+0.122 G+0.162 H_{o}$ \\
\hline
\end{tabular}

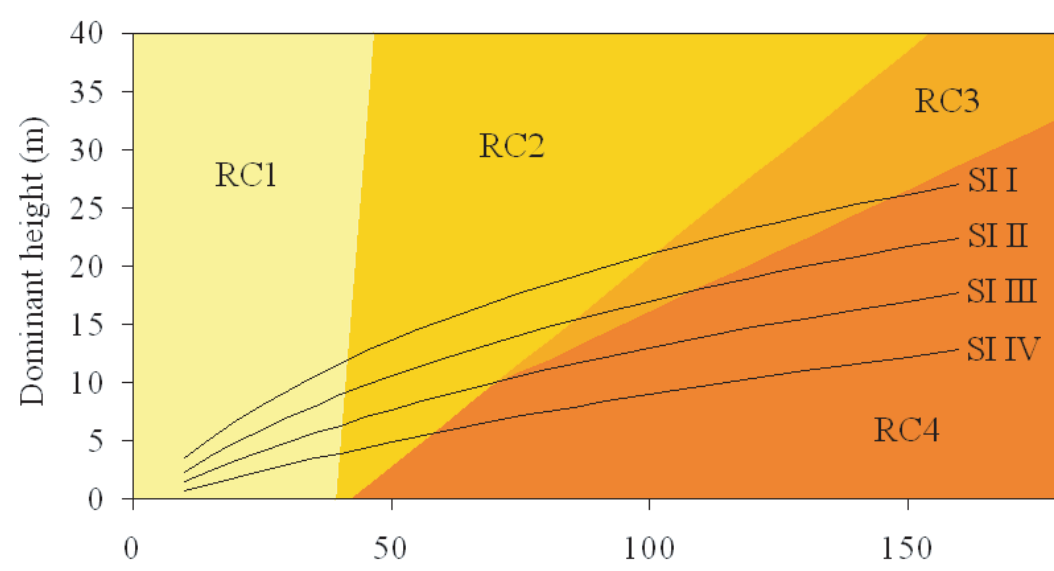

Age of the stand (years)
Figure 5. Site index curves (SI I, SI II, SI III, SI IV) fitted by Calama et al. [4] overlapped with the diagram of the four rot risk classes (RC1, RC2, RC3 and RC4) as a function of the age and the dominant height of the stand using the discriminant functions of García and Montero [13] from Table III for an average basal area of $18 \mathrm{~m}^{2} / \mathrm{ha}$. (A color version of this figure is avialable at www.edpsciences.org/forest.)
180-200 year age classes occupy the same area, so no regeneration fellings are carried out in the 160-180 class.

\subsection{Division of the working plan area}

The sum of the areas to be felled and regenerated throughout the forest that must be equal to the area in the first age class given by the theoretical model in Figure 2 (60.57 ha). In areas with a site index of III (Fig. 4) the regeneration fellings will start at 80 years, so $1 / 4\left(T_{b} / t=4\right)$ of that area $(16.8 \mathrm{ha}$ approximately) must be regenerated in the following 20 years. The rest of the regeneration area, up to 60.57 ha, should have a site index of I or II. Within the same age class, the areas which passes on to the next age class will be selected among those located in better qualities, according to productivity and ecological conditions. In those areas where the site index is I or II, the area to be occupied by each age class above 80 years in Figure 2 must be selected from the preceding age class stands. Figure 6 shows the proposed spatial arrangement of the felling zones in the forest for the next two regeneration periods and the additional areas removed under periodic block management with a 80 years rotation.

\subsection{Estimation of timber and pine nut production losses}

The silvicultural method most widely used in Pinus pinea forests is the shelterwood system [24], and the management
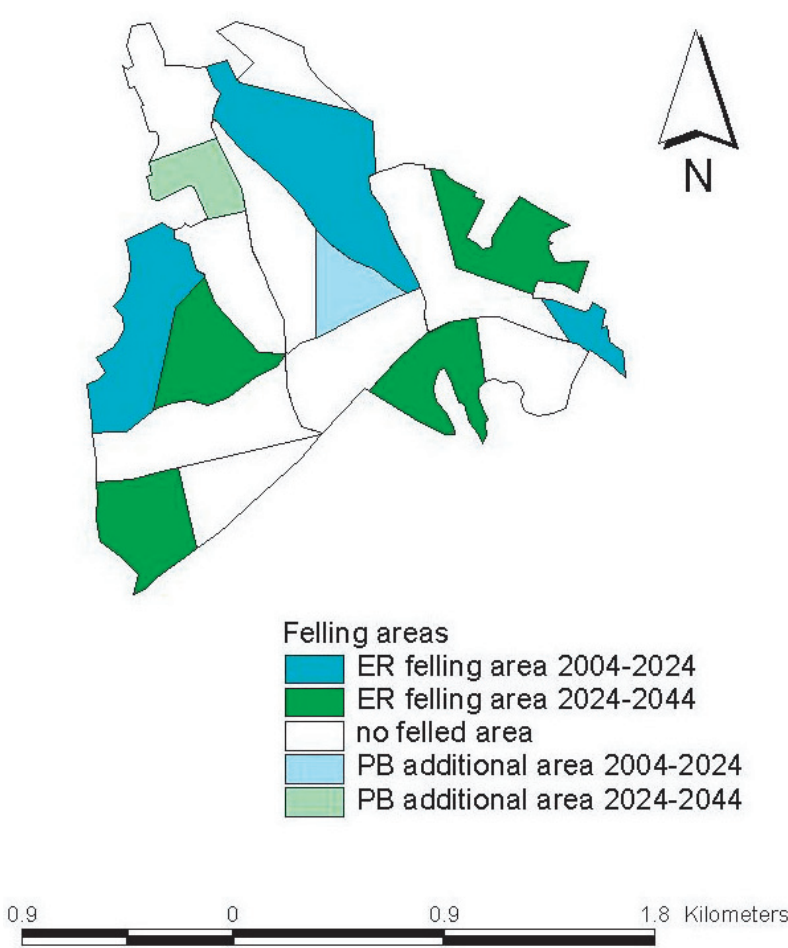

Figure 6. Spatial arrangement of the felling areas planned for the periods 2004-2024 and 2024-2044 under extended length rotation (ER) system and additional felling areas under periodic blocks (PB) system. (A color version of this figure is avialable at www.edpsciences.org/forest.) 
Table IV. Cone and timber production under periodic blocks (PB) and extended rotation (ER) methods for the studied period and the production increment or loss under ER method with respect to $\mathrm{PB}(\Delta)$.

\begin{tabular}{|c|c|c|c|c|c|c|c|}
\hline & \multicolumn{3}{|c|}{ 2004-2024 period } & \multicolumn{3}{|c|}{ 2024-2044 period } & \multirow{2}{*}{ Total $\Delta(\%)$} \\
\hline & PB & ER & $\Delta(\%)$ & PB & ER & $\Delta(\%)$ & \\
\hline Area with cone production (ha) & 206.60 & 215.12 & 4.12 & 138.13 & 154.50 & 11.85 & 7.22 \\
\hline Cone production $(\mathrm{t})$ & 742 & 779 & 4.99 & 880 & 1003 & 13.98 & 9.86 \\
\hline Felled area (ha) & 69.40 & 60.88 & -12.28 & 68.47 & 60.17 & -12.12 & -12.20 \\
\hline Total timber production $\left(\mathrm{m}^{3}\right)$ & 9025 & 7832 & -13.22 & 11451 & 9591 & -16.24 & -14.91 \\
\hline Saw timber production $\left(\mathrm{m}^{3}\right)$ & 5617 & 4920 & -12.41 & 7715 & 6362 & -17.54 & -15.38 \\
\hline
\end{tabular}

system usually applied is the periodic blocks (PB) system, that consists of dividing the management unit into a number of periodic blocks to be felled and regenerated during the course of successive periods, each of the periodic blocks formed by several forest compartments scattered throughout the management unit $[22,23]$. In the PB system, all the periodic blocks have similar area and are managed under the same rotation length. The ER method was compared with PB on the basis of both cone and timber production attained during two consecutive regeneration periods: 2004-2024 and 2024-2044 (Tab. IV). The future stage and production of the plots has been simulated using the single tree dynamic growth and yield model for the species developed by Calama [5]. The values of the growing stock and cone production obtained for the plots were used to estimate the forest compartment figures through ordinary block kriging (see Section 3.2.2). In order to estimate cone production, we have taken into account that cone collection is forbidden in regeneration areas and that commercial cone production is practically negligible in forest areas under 40 years old. Estimated wood production only considers the timber felled in regeneration cuttings. From the Table IV it can be seen that the extended rotation method leads to a larger area in which cones can be collected, therefore increasing the total pine nuts crop. The reservation of these "over-mature" areas, which maintain a significant cone production, leads to a reduction in both saw timber (diameter $>25 \mathrm{~cm}$ ) and total timber production, together with a decrease in timber quality, derived from increment in probability for stem rot affection.

\subsection{Characterisation of structural diversity}

The structural diversity of the stand was assessed through the diversity of the age distribution and the diversity related to the basal area distribution heterogeneity. As an indicator of the age distribution diversity, the Shannon's index was calculated with proportions of forest area corresponding to each age class $[21,34]$ :

$$
H^{\prime}=-\sum_{i=1}^{s} p_{i} \ln p_{i}
$$

where $p_{i}$ is the ratio between the area in the $i$ th age class and the total forest area calculated through the age histogram obtained from the inventory plots and $s$ the number of age classes, the age class width being 20 years.

Similarly, to assess the spatial variability of the tree distribution, the forest area was classified by basal area classes of 5 $\mathrm{m}^{2}$ width, calculating the Shannon's diversity index (Eq. (7)) with the proportions corresponding to each basal area class. Both indices were calculated at the beginning of the first period (year 2004) and at the end of each period (i.e., years 2024 and 2044). As Table V shows, both indicators of the structural diversity increased after 40 years when ER method is applied with respect to $\mathrm{PB}$ due to the increment of the age range within the forest and the large basal area associated with the areas in the upper age classes.

\section{DISCUSSION}

The extended rotation method proposed in this paper may be an option for multi-purpose forest management. The basis of the proposed method is a theoretical division of the forest in several management circles (Fig. 1). In practice, this theoretical age distribution can be established by retaining, from each $i$ th age class, the area that the $i$ th +1 age class might occupy in the proposed model, calculated by Equation (2).

Only a part of the area occupied by each age class beyond the base rotation is retained to pass to the next age class, whereas the rest of the area occupied by that age class must be regenerated during each period. Furthermore, the increment rate decreases earlier in those stands that have a lower site index (Fig. 5), so to minimize the timber yield loss, the areas that pass on to the next age class must be those that have a better site quality. This procedure is similar to that which occurs in the development of natural stands, where those located in better sites survive longer [33], so many species that live in seral stages stands are associated to high quality site conditions [6]. Moreover, since the risk of stem rot increases earlier in stands located on poor quality sites (Fig. 5), and also because better site quality results in greater cone production, the rotation must be shorter in zones with a low site index, whereas in zones with a high site index the rotation could be longer. However, there could be another criteria, as the aesthetical value or the protective function, concerned in the spatial arrangement of the areas where longer rotations are used.

The main management objectives, the longevity of the species and the natural disturbance regime may be taken into account when choosing the most suitable age structure for each different forest system. If timber production is the main objective, then the larger zone, were the rotation is $T_{b}$, may be greater. The maximum age $(T+(N-1) \times t)$ depends on the longevity of the species and the rate from the forest area 
Table V. Shannon's diversity index with proportions of forest area corresponding to each age class and basal area class under periodic blocks (PB) and extended rotation (ER) methods for the studied period and the increment or loss under ER method with respect to $\operatorname{PB}(\Delta)$.

\begin{tabular}{lccccccc}
\hline & \multirow{2}{*}{ Year 2004 Year 2024 } & \multicolumn{3}{c}{ Year 2044 } \\
\cline { 2 - 8 } & & PB & ER & $\Delta(\%)$ & PB & ER & $\Delta(\%)$ \\
\hline Age distribution diversity & 1.41 & 1.33 & 1.42 & 6.03 & 1.58 & 1.68 & 6.68 \\
Basal area diversity & 1.48 & 1.72 & 1.72 & 0.00 & 1.79 & 1.91 & 6.54 \\
\hline
\end{tabular}

to the minimum area necessary to apply the silvicultural system chosen, which in turn depends on the tolerance to shade and competition of the species. $r_{i}$ could also be defined as constant for all the management circles or by an arithmetic series, giving similar age distributions, but that may emulate different decline rates: if $r_{i}$ is constant, the rate of felled surface during the age classes beyond the base rotation is constant, so the retained surface decreases quicker than under the series given by Equation (3). $r_{i}$ may be constant, for example, for cork oak, because the debarking causes harm to the trees, so after 9-10 times the cork extraction bring about the decay of the trees [25] and, therefore, of the production. The series given by Equation (3) is more suitable in the case of study, because the pines with largest cone production usually keep a large production till more than 150 years. If the aim is the conservation of some protected or rare species, the criteria to determine $r_{i}$ must be to maintain the extent of habitat to support certain population.

By choosing the areas with a larger cone production to pass on to the next age class, the pine nut production is improved with the prolongation of the rotation length, not only because it is increased, but also the production is concentrated in more productive trees. For the studied period, the application of the extended rotation lead to about $15 \%$ loss in timber production but a $10 \%$ increment in cone production when compared with the use of periodic blocks (Tab. IV). Cone production shows an increasing trend, since the reserved areas are those with the greatest cone production and should keep on producing cone crops until they reach an age of 180-200 years. In any case, under market conditions in which pine nuts are more profitable than timber, as is currently the case, the extended rotation method is an alternative worth considering.

This model can be used to define the age distribution under silvicultural systems based on even-aged stands (such as the uniform system and the group system) that are easy controlled by area.

The use of extended length rotations leads to higher structural diversity than fixed rotations, as Table V shows, and may be seen as a compromise between production and conservation. Sustainability requires a balanced management for both ecological and socio-economic objectives. The proposed model is flexible and easily adapted to different silvicultural systems and forest types. The variable age of maturity is a characteristic of many Mediterranean forests where, apart from timber, the main production may be other non timber for- est products (as cork, resin or pine nut) or in some cases the forest might have an important protective function. In other temperate forests with small rot affection, this method can be used to reserve some trees or groups of trees in high forests to produce large sized logs or veneer timber [23]. The ER method can provide different target age distributions for evenaged stands, thereafter it would be interesting to use optimisation methods $[8,37]$ for multiple objectives including the age distribution given by ER as constrains.

Acknowledgements: The authors wish to thank Miguel Cabrera, Alfonso San Miguel and Gregorio Montero their collaboration in improving the manuscript, to Adam Collins the language revision and to Mercedes Guijarro the French abstract revision.

\section{REFERENCES}

[1] Baudin F., Ordenación y selvicultura intensiva en los montes de P. pinea. Su financiación, Montes 34 (1963) 241-244.

[2] Berger A.L., Puettmann K.J., Overstory composition and stand structure influence herbaceous plant diversity in the mixed aspen forest of northern Minnesota, Am. Midl. Nat. 143 (2000) 111-125.

[3] Bergeron Y., Leduc A., Harvey B.D., Gauthier S., Natural fire regime: a guide for sustainable management of the Canadian boreal forest, Silva Fenn. 36 (2002) 81-95.

[4] Calama R., Cañadas N., Montero G., Inter-regional variability in site index models for even-aged stands of stone pine (Pinus pinea L.) in Spain, Ann. For. Sci. 60 (2003) 259-269.

[5] Calama R., Modelo interregional de selvicultura para Pinus pinea L. Aproximación mediante funciones con componentes aleatorios, Ph.D. thesis, Universidad Politécnica de Madrid, 2004.

[6] Camprodon i Subirachs J., Tratamientos forestales y conservación de fauna vertebrada, in: Camprodon i Subirachs J., Plana E. (Eds.), Conservación de la biodiversidad y gestión forestal. Su aplicación en la fauna vertebrada, Edicions Universitat de Barcelona, Barcelona, 2001, pp. 135-182.

[7] Cressie N.A.C., Statistics for Spatial Data, Wiley, New York, 1993.

[8] Falcão A.O., Borges J.G., Designing decision support tools for Mediterranean forest ecosystems management: a case study in Portugal, Ann. For. Sci. 62 (2005) 751-760.

[9] Ferris R., Peace A.J., Humphrey J.W., Broome A.C., Relationships between vegetation, site type and stand structure in coniferous plantations in Britain, For. Ecol. Manage. 136 (2000) 35-51.

[10] Franklin J.F., Spies T.A., Van Pelt R., Carey A.B., Thornburgh D.A., Rae Berg D., Lindenmayer D.B., Harmon M.E., Keeton W.S., Shaw D.C., Bible K., Chen J., Disturbances and structural development of natural forest ecosystems with silvicultural implications, using Douglas-fir forests as an example, For. Ecol. Manage. 155 (2002) 399-423.

[11] Führer E., Forest functions, ecosystem stability and management, For. Ecol. Manage. 132 (2000) 29-38.

[12] García C., Modelo de simulación selvícola para Pinus pinea L. en la provincia de Valladolid, P.D. thesis, Universidad Politécnica de Madrid, 2000.

[13] García C., Montero G., Influencia de ciertas variables selvícolas en la pudrición provocada por Phellinus pini sobre Pinus pinea, Investig. Agr. Sist. Recur. For. 7 (1998) 203-218.

[14] Hale C.M., Pastor J., Rusterholtz K.A., Comparision of structural and compositional characteristics in old growth and mature, managed hardwood forest of Minnesota, USA, Can. J. For. Res. 29 (1999) 1479-1489. 
[15] Harvey B.D., Leduc A., Gauthier S., Bergeron Y., Stand-landscape integration in natural disturbance-based management of the southern boreal forest, For. Ecol. Manage. 155 (2002) 369-385.

[16] Hunter M.L., Biological diversity, in: Hunter M.L. (Ed.), Maintaining biodiversity in forest ecosystems, Cambridge University Press, Cambridge, UK, 1999.

[17] Journel A.G., Huijbregts C.J., Mining geostatistics, Academic Press, London, 1978.

[18] Kerr G., The use of silvicultural systems to enhance the biological diversity of plantation forests in Britain, Forestry 72 (1999) 191204.

[19] Kuuluvainen T., Penttinen A., Leinonen K., Nygren M., Statistical opportunities for comparing stand structural heterogeneity in managed and primeval forests: An example from boreal spruce forest in southern Finland, Silva Fenn. 30 (1996) 315-328.

[20] Mackay E., Fundamentos y métodos de la Ordenación de Montes. Primera parte: Conceptos fundamentales, Ordenación teórica, Escuela Especial de Ingenieros de Montes, Madrid, 1944.

[21] MacArthur R.M., MacArthur J.W., On bird species diversity, Ecology 42 (1961) 594-598.

[22] Madrigal A., Ordenación de montes arbolados, ICONA, Ministerio de Agricultura, Pesca y Alimentación, Madrid, 1994.

[23] Matthews J.D., Silvicultural systems, Oxford University Press, Oxford, 1989.

[24] Montero G., Candela J.A., Rodríguez A., El pino piñonero (Pinus pinea L.) en Andalucía, Dirección General de Gestión del Medio Natural, Consejería de Medio Ambiente, Junta de Andalucía, Sevilla, 2004.

[25] Montero G., Cañellas I., Selvicultura de los alcornocales en España, Silva Lusitana 11 (2003) 1-19.

[26] Nagaike T., Hayashi A., Effects of extending rotation period on plant species diversity in Larix kaempferi plantations in central Japan, Ann. For. Sci. 61 (2004) 197-202.
[27] North M.P., Franklin J.F., Carey A.B., Forsman E.D., Hamer T., Forest stand structure of the northern spotted owl's foraging habitat, For. Sci. 45 (1999) 520-527.

[28] Palik B., Engstrom R.T., Species composition, in: Hunter M.L. (Ed.), Maintaining biodiversity in forest ecosystems, Cambridge University Press, Cambridge, UK, 1999.

[29] Schieck J., Stuart-smith K., Norton M., Bird communities are affected by amount and dispersion of vegetation retained in mixedwood boreal forest harvest areas, For. Ecol. Manage. 126 (2000) 239-254.

[30] Schütz J.P., Close-to-nature silviculture: is this concept compatible with species diversity? Forestry 72 (1999) 359-366.

[31] Seymour R., Hunter M.L., Principles of ecological forestry, in: Hunter M.L. (Ed.), Maintaining biodiversity in forest ecosystems, Cambridge University Press, Cambridge, UK, 1999.

[32] Siitonen J., Martikainen P., Punttila P., Rauh J., Coarse woody debris and stand characteristics in mature managed and old-growth boreal mesic forests in southern Finland, For. Ecol. Manage. 128 (1999) 211-225.

[33] Spies T., Turner M., Dynamic forest mosaics, in: Hunter M.L. (Ed.), Maintaining biodiversity in forest ecosystems, Cambridge University Press, Cambridge, UK, 1999.

[34] Staudhammer C.L., LeMay V.L., Introduction and evaluation of possible indices of stand structural diversity, Can. J. For. Res. 31 (2001) 1105-1115.

[35] Sturtevant B.R., Bissonette J.A., Long J.N., Roberts D.W., Coarse woody debris as a function of age, stand structure, and disturbance in boreal Newfoundland, Ecol. Appl. 7 (1997) 702-712.

[36] Uuttera J., Maltamo M., Hotanen J.P., The structure of forest stands in virgin and managed peatlands: a comparison between Finnish and Russian Karelia, For. Ecol. Manage. 96 (1997) 125-138.

[37] Van Deusen P.C., Multiple solution harvest scheduling, Silva Fenn. 33 (1999) 207-216.

[38] Yagüe S., Silviculture and production of stone pine (Pinus pinea L.) stands in the province of Avila (Spain), Proceedings of the IUFRO Meeting on Mountain Silviculture, Valsaín, 1984, pp. 433-444. 